\title{
Retirement and Home Production: A Regression Discontinuity Approach
}

\author{
Elena Stancanelli* and Arthur Van Soest ${ }^{* *}$
}

\begin{abstract}
Existing studies show that individuals who retire replace some private consumption by home production, but do not consider joint behaviour of couples. Here we analyze the causal effect of retirement of each partner on hours of home production of both partners in a couple. Our identification strategy exploits the earliest age retirement laws in France, enabling a fuzzy regression discontinuity approach. We find that own retirement significantly increases own hours of home production and the effect is larger for men than for women. Moreover, retirement of the female partner significantly reduces male hours of home production but not vice versa.
\end{abstract}

\section{Introduction}

Existing studies argue that the drop in consumption expenditures upon retirement, known as the retirement consumption puzzle, may be at least partly explained by increased home

\footnotetext{
*CNRS, THEMA, University Cergy Pontoise and OFCE, Sciences-Po, Paris, Email: elena.stancanelli@sciences-po.fr.
}

***Tilburg University, Netspar, Address: P.O. Box 90153, 5000 LE Tilburg, The Netherlands, Email: avas@uvt.nl.

This paper has benefited from useful comments of the participants of the conference in honor of Gary Becker in Paris, October 2011, the July 2011 NBER summer institute on Aging, the June 2010 IZA time use conference at Maryland University, the April 2010 SOLE conference in Vancouver, the January 2010 Netspar conference Amsterdam, the 2010 CNRS winter school in Aussois and the gender seminar at University Paris 1, Sorbonne Pantheon. 
production. The earlier literature focuses on retirement of the male head of the household and its effects on consumption and individual home production. However, retirement of one (or both) of the partners in a couple may change the way in which both partners spend their time.

In this paper we analyze the causal effect of retirement on hours of home production of individuals in a couple, allowing for endogeneity of the retirement decision. Our identification strategy exploits the legislation on the earliest age at which a retirement pension can be drawn in France. This makes the probability to be in retirement a discontinuous function of age, with a substantial positive jump at age 60 . We therefore can use a (fuzzy) regression discontinuity approach: keeping retirement status constant, time spent on home production is assumed to be a continuous function of the age of both partners in the couple, whereas the probability of retirement is discontinuous at age 60 (of the individual and, possibly, the spouse). In other words: the age at least 60 dummies for both partners can be excluded from the equations for the time spent on home production, but do have explanatory power in the equations for retirement.

Retirement may directly affect the marginal utility of home production and make it attractive to spend more time on it, while at the same time reducing expenditures on consumption goods and services bought in the market. Not only the home production of the partner who retires (and has more time available for home production, leisure activities, etc.) may increase - There may also be an effect on home production of the other partner, induced by the change in home production of the retiring partner, or to compensate for a reduction in household income. This is why in our model we analyze how retirement of one (or both) of the partners in a couple affects the hours of home production of both partners. 
The relation between life cycle consumption or home production and retirement has been studied extensively (see, for example, Daniel Hamermesh, 1984; Eric Hurst, 2008; Erich Battistin et al., 2009; Mark Aguiar and Erik Hurst, 2005 and 2007a; Michael Hurd and Susann Rohwedder, 2008). None of these earlier studies considered the retirement of the partner. On the other hand, in the scant literature on partners' joint retirement decisions, one of the explanations for joint retirement is externalities in leisure: joint retirement makes it possible to derive utility from joint leisure activities that exceeds the utility from leisure activities without the partner (Michael Hurd, 1990; Alan Gustman and Thomas Steinmeier, 2000 and 2009). These studies did not consider how joint retirement may affect household consumption or home production.

We analyze the effect of retirement of both partners on various home production activities, including shopping, cooking, gardening, and, more generally, doing household chores, and caring for adults and children. All these activities are enjoyable (or better, dislikeable) to different extents and have obvious market substitutes in the form of maids, gardeners, private enterprises, and public or private care providers.

The data for the analysis are drawn from the 1998-99 French Time Use Survey, carried out by the French National Statistical Offices (INSEE). The sample includes about 1,000 couples where each partner was aged 50 to 70 at the time of the survey. In our data, age is available in months, which is helpful to identify respondents very close to the age threshold of 60 .

We find that the probability to be retired and the expected number of hours of paid work have a substantial and statistically significant discontinuity at age 60, supporting our identification strategy. Our results show that retirement not only increases own house work time, but also affects the partner's time allocation. Therefore, controlling for both partners' retirement is crucial to understanding the effect of retirement on home production. 
The structure of this paper is the following. The next section presents the econometric approach. Description of the data follows. The last section discusses the results of the estimations and draws conclusions.

\section{A Regression Discontinuity Approach}

To identify the causal effect of retirement on home production, we exploit the legislation on early retirement in France, which sets 60 as the earliest retirement age for most workers. This creates a discontinuity in the probability of retirement as a function of age that enables us to apply a regression discontinuity (RD) framework (see, for example, David Lee and Thomas Lemieux, 2010, for a review of RD).

In our data, year and month of birth were collected, so we can treat age as measured continuously. Our approach accounts for the fact that some people retire earlier than sixty due to special early retirement schemes and sector specific agreements - and others later. ${ }^{1}$ It follows that we face a "fuzzy" regression discontinuity design: the jump in the probability of retirement at age 60 is greater than zero but less than one.

Let $R_{m}$ and $R_{f}$ be dummies for retirement of the male (m) and female (f) partners, equal to one for individuals who have retired from market work and zero otherwise, and let $\mathrm{T}_{\mathrm{jm}}$ and $\mathrm{T}_{\mathrm{jf}}$ be the hours allocated to house work of type $\mathrm{j}$. Our model specification is as follows:

$$
\begin{aligned}
& T_{j m}=\mathbf{Z}_{\mathbf{m}} \boldsymbol{\beta}^{\mathrm{tjm}}+\mathbf{Z}_{\mathbf{f}} \boldsymbol{\beta}^{\mathrm{tjf}}+R_{m} \gamma^{\mathrm{tjm}}+R_{f} \gamma^{\mathrm{tjf}}+\operatorname{Agepol}_{\mathbf{m}} \psi^{\mathrm{tjm}}+\operatorname{Agepol}_{\mathbf{f}} \psi^{\mathrm{tjf}}+v^{\mathrm{tjm}} \\
& T_{j f}=\mathbf{Z}_{\mathbf{m}} \lambda^{\mathrm{tjm}}+\mathbf{Z}_{\mathbf{f}} \lambda^{\mathrm{tjf}}+R_{m} \delta^{\mathrm{tjm}}+R_{f} \delta^{\mathrm{tjf}}+\operatorname{Agepol}_{\mathbf{m}} \zeta^{\mathrm{tjm}}+\operatorname{Agepol}_{\mathbf{f}} \zeta^{\mathrm{tjf}}+v^{\mathrm{tjf}}
\end{aligned}
$$

\footnotetext{
${ }^{1}$ In France, labor force participation interruptions will not translate into later pension entitlement since unemployment and sick leave periods all contribute to the pension claim.
} 


$$
R_{i m}{ }^{*}=\mathbf{Z}_{\mathbf{m}} \boldsymbol{\beta}^{\mathrm{rm}}+\mathbf{Z}_{\mathbf{f}} \boldsymbol{\beta}^{\mathbf{r f}}+D_{m} \gamma^{\mathrm{rm}}+\mathbf{A g e}_{\mathbf{m}} D_{m} \boldsymbol{\eta}^{\mathrm{rm}}+\mathbf{A g e}_{\mathbf{m}}\left(1-D_{m}\right) \boldsymbol{\pi}^{\mathrm{rm}}+D_{f} \gamma^{\mathrm{rf}}+
$$

$+\mathbf{A g e}_{\mathbf{f}} D_{f} \boldsymbol{\eta}^{\mathbf{r f}}+\operatorname{Age}_{\mathbf{f}}\left(1-D_{f}\right) \boldsymbol{\pi}^{\mathbf{r f}}+v^{\mathrm{rm}} ; R_{i m}=1$ if ${R_{i m}}^{*}>0$ and $R_{i m}=0$ if $R_{i m}{ }^{*} \leq 0$

$$
R_{i f}{ }^{*}=\mathbf{Z}_{\mathbf{m}} \lambda^{\mathbf{r m}}+\mathbf{Z}_{\mathbf{f}} \lambda^{\mathbf{r f}}+D_{m} \delta^{\mathrm{rm}}+\operatorname{Age}_{\mathbf{m}} D_{m} \boldsymbol{\tau}^{\mathrm{rm}}+\operatorname{Age}_{\mathbf{m}}\left(1-D_{m}\right) \boldsymbol{\mu}^{\mathrm{rm}}+D_{f} \delta^{\mathrm{rf}}+
$$

$+\operatorname{Age}_{\mathbf{f}} D_{f} \boldsymbol{\tau}^{\mathbf{r f}}+\operatorname{Age}_{\mathbf{f}}\left(1-D_{f}\right) \boldsymbol{\mu}^{\mathbf{r f}}+v^{\mathrm{rf}} ; R_{i f}=1$ if $R_{i f}{ }^{*}>0$ and $R_{i f}=0$ if $R_{i f}{ }^{*} \leq 0$

Here $\mathbf{A g e}_{\mathbf{m}}=\left[\left(A g e_{m}-60\right),\left(\operatorname{Ag}_{m}-60\right)^{2}, \ldots,\left(A g e_{m}-60\right)^{\mathrm{n}}\right]$

$$
\begin{aligned}
& \text { Age }_{\mathbf{f}}=\left[\left(A g e_{\mathrm{f}}-60\right),\left(A g e_{f}-60\right)^{2}, \ldots,\left(A g e_{f}-60\right)^{\mathrm{n}}\right] \\
& \text { Agepol }_{\mathbf{m}}=\left[\left(A g e_{m}\right),\left(A g e_{m}\right)^{2}, \ldots,\left(A g e_{m}\right)^{\mathrm{n}}\right] \\
& \text { Agepol }_{\mathbf{f}}=\left[\left(A g e_{f}\right),\left(A g e_{f}\right)^{2}, \ldots,\left(A g e_{f}\right)^{\mathrm{n}}\right]
\end{aligned}
$$

The vectors $\mathbf{Z}_{\mathbf{m}}$ and $\mathbf{Z}_{\mathbf{f}}$ contain control variables (other than age functions) such as education level, presence of children, and local labor market variables like the regional unemployment rate; $D_{m}$ and $D_{f}$ are dummies for whether the male and female partners have reached age 60 (720 months of age); Greek letters denote (vectors of) coefficients. The v's are normally distributed errors, independent of $\mathbf{Z}_{\mathbf{m}}$ and $\mathbf{Z}_{\mathbf{f}}$ and the ages of both partners but allowed to be correlated across equations. The equations for retirement are probits; the hours of house work equations are linear equations. ${ }^{2}$ The four equations are estimated jointly with simulated maximum likelihood. Since the error terms in equations (1) - (4) are allowed to be correlated in an arbitrary way, own and partner's retirement are allowed to be endogenous to house work.

Alternatively, we also analyze models in which retirement is replaced by hours of paid (market) work. This model uses the same explanatory variables and identification strategy,

\footnotetext{
${ }^{2}$ We also experimented with tobit equations to account for the bunching of some house work activities at zero and the results were comparable.
} 
since reaching age 60, through retirement, leads to a discontinuous drop in average hours of market work (given the control variables).

We also use similar models for the sum of the male and female partner's hours of house work, using a system of three instead of four equations: two retirement equations (one for each partner) and one house work equation at the household level. The advantage of this is that it makes it easier to interpret the effect of retirement of one or both partners on the total hours allocated to home production by the couple.

Finally, since most individuals do not perform market work at weekends, retirement might simply lead to a reallocation of house work from weekends to week days. We therefore also consider observations on time use on weekend days, including a weekend dummy and its interactions with the retirement dummies (or market hours) in the home production equations, as well as interactions of the 'age at least 60' dummies and weekend diary dummies in the market hours equations.

\section{The data}

\section{Sample selection and covariates}

The data for the analysis are drawn from the 1998-99 French time use survey, carried out by the National Statistical offices (INSEE). This survey is a representative sample of more than 8,000 French households. We then applied the following criteria to select our estimation sample out of the 5,287 heterosexual couples surveyed:

- Both partners responded to the survey and were aged 50 to 70 .

- Both partners filled in the time diary. 
- The partners did not fill in the time diary on an atypical day, defined as a special occasion such as a vacation day, a day of a party, a funeral, or a sick day.

- None of the partners were unemployed or inactive.

- We dropped one man who reported to be a home-maker, but we kept housewives.

Applying these criteria led to a sample of 1043 couples. We distinguish the following time use categories collected in the diary:

1. Market work (at the workplace or at home, etc.)

2. House work, and its subcomponents:

i. 'Core' household work, including cleaning, doing the laundry, ironing, cleaning the dishes, setting the table, and doing administrative paper work for the household

\section{ii. Shopping}

iii. Cooking

iv. "Other" household work, including gardening, house repairs, knitting, sewing, making jam, and taking care of pets

3. Caring for children and/or adults living in the same or in other households

We separate cooking and shopping activities from other 'core' chores as these two activities are the ones that received most attention in the earlier literature on substituting home production for private expenditure (for instance, Aguiar and Hurst, 2005 and 2008). We also single out 'other' house work, sometimes named "semi-leisure' chores in the time use literature, since well be more enjoyable tasks than other sorts of house work (see, for example, Aguiar and Hurst, 2007b). Finally, we separate care tasks from other household chores since earlier studies for similar reasons. 
The employment or retirement status is derived from the respondent's self-assessed occupational status. In particular, respondents were asked to choose among the following possible states: employment; unemployment; in education; in the military; retired or earlyretired; housewife; other inactive. The indicator for retirement takes value one for respondents that self-reported to be retirees or early-retirees. In the analysis, housewives will be considered together with retired women ${ }^{3}$, as opposed to those employed and thus, still at work. This adds to the motivation for also looking at the drop in hours of paid (market) work, since being retired here does not automatically translate into a fall to zero paid hours.

\section{Descriptive statistics}

Descriptive statistics are given in Table1. We have selected a sample with both partners aged between 50 and 70 years (see Section 3.1). Women are on average two years younger than their husbands. About 57 per cent of the men and 43 of the women in a couple, in our sample, are aged 60 or above. About 64 per cent of the men and 67 per cent of the women in the sample have retired from market work (see Section 3.2 for our definition of retirement). The percentage employed is 36 for men and 32 per cent for women. Only a small minority of individuals were not born in France: 4 per cent of the men and 3 per cent of the women. The majority of individuals have less than high school (the benchmark). Men tend to be slightly more educated than women: 12 (10) per cent of husbands (wives) have completed high school (12 years of schooling) and 15 (11) per cent have a higher education level (over twelve years of schooling). Only 15 per cent of the sample have children still living in the parental home. Only 4 per cent of couples are cohabiting; the others are formally married. Very few couples ( 2 per cent) were living in central Paris. The mean level of unemployment at the time was pretty high, over 11 per cent.

These findings are due to a combination of having selected older generations and only those in a couple, as younger generations in France tend to be more educated and are more often

\footnotetext{
${ }^{3}$ We also experimented with dropping couples where the female partner reported to be a housewife from the sample, and this did not substantially affect the results, though the sample size drops to about 700 households.
} 
cohabiting. Only three per cent of the men and five per cent of the women in our sample reported to have a bad general health status. About 23 per cent of the observations filled in the time diary on a weekend.

Descriptive statistics of participation and hours for the activities considered (see Section 3.2 for more details) are provided in Table 2.

In line with below average employment rates, only 30 per cent of the men and 22 per cent of the women report any market hours on the day the diary was collected, but note that 23 per cent of these days fell on a weekend. Average market work including the zeros is slightly over two hours a day for men and slightly less than an hour and a half for women. The median of hours of market work is zero for both partners. Using a standard definition of housework, that includes all chores, 87 per cent of the husbands and 99 per cent of the wives report doing some house work on the diary day. On average, husbands spends three hours on it and wives five hours, on a given day -which might be a weekend day. Excluding 'other' chores, the amount of 'core' housework (which includes cleaning, cooking, shopping, washing clothes, ironing, doing the dishes, and doing administrative paper work) done by husbands falls dramatically, to one hour and a quarter, on average, while for women the difference is only half an hour less. The median man spends indeed an hour on 'other' chores (gardening, house repairs, etc, see list in Section 3.2) against no time at all for the median woman in our couple sample. Participation in these tasks is almost 62 per cent for husbands against 44 per cent for wives. To give some order of reference, the participation rate in cooking is 93 per cent for women and 30 per cent for men while 41 per cent of the men and 52 per cent of the women do some shopping on the diary day.

Finally, we provide some information on care activities by the individuals in our sample. This variable includes care provided to children and adults living at home or belonging to other households and it includes performing house work for adults in other households for no charge (see Section 3.2 for more details). The participation rates are 15 per cent for men and 22 per cent for women; the average time allocated to it on the diary day is 18 minutes for men and 24 for women.

Of course, all these comparisons relate to our sample of older couples; the picture may be quite different for singles or younger people. 


\section{Results}

First, we have carried out some exploratory graphical analysis of the discontinuities in retirement, market hours, and house work at age 60 for each partner (see Charts 1 and 2). We have found evidence of a clear discontinuity in retirement and hours of paid work at the age cutoff of 60 for both men and women There is a substantial jump at age 60 for some of the home production activities considered.

Estimation results of the four equations model of retirement and hours of home production of each partner are summarized in Tables 3 . We find that at (own) age 60, the probability to be retired increases significantly and market hours drop significantly, which supports our identification strategy. The fact that partner reaches age sixty has no significant effect on individual retirement (market hours). A few other variables are significant: respondents living in Paris tend to retire later, as do respondents with higher education level.

We find that own retirement increases significantly husband's and wife's house work hours. Retirement leads to a significant increase of own hours of home production of more than three hours per week day for men and two hours and forty minutes for women. This large increase in house work hours partly reflects the fact that upon retirement a considerable amount of time is reallocated to other 'productive' activities. Moreover, the wife's retirement leads to a significant reduction of the husband's hours of home production of almost two hours per day, while her house work does not respond significantly to his retirement. Men living in Paris tend to do less housework than other men. For women, cohabiting instead of marriage and education are negatively related to the time spent on housework. Finally, the strongly significant and positive correlations between the unobservables driving the retirement decisions of the two partners (Tables 5 and 6) reflect a tendency to retire jointly. The positive and significant correlation between unobservables in the two partners' house work equations 
suggests that shared preferences or prices of market alternatives to home production are more important than substitution patterns.

Estimation results for the model with hours of paid work instead of retirement are more or less the "mirror" image of this (Table 4). Own hours of paid work fall dramatically and significantly upon reaching age 60 for both partners, with a larger effect for men than for women. As expected, the drop in market hours at age 60 is much larger on week days than on weekends. ${ }^{4}$ Whether the partner is 60 or older has no significant impact on own market hours. Each additional hour of market work substantially reduces own house work hours for both partners, though the effect is significant at only the ten per cent level for women. For men, a one hour drop in market work on a week day results in an increase of own home production of about 25 minutes. For women, the effect is somewhat less than 20 minutes. On weekend days, the effects are smaller, particularly for men. Women hardly respond to a change in market hours of the husband. Men respond more to a change in female market hours, and the effect is positive, as expected, but it is significant only on weekend days. The larger response of male house work to the woman's hours of paid work than vice versa is in line with the larger response of male house work to the woman's retirement discussed above.

The effects of retirement of each partner on the total housework hours at the household level (see Table 8) indicate that total house work increases by about four hours on a weekday following retirement of the husband, ${ }^{5}$ while the retirement status of the wife does not have a

\footnotetext{
${ }^{4}$ As reflected by the large negative estimates for the dummy on weekend day diaries, hours of paid work are much lower in weekends than on weekdays, for males as well as females and before and after age 60. It In other words, few people in couples and in the age group 50-70 worked on a weekend day in France in 1998.

5 A drop of one hour in the husband's paid work translates into half an hour more house work at the household level (Table 9).
} 
significant effect: the negative effect on house work by the husband and the positive effect on own house work largely cancel out. This shows the importance of considering house work of both partners in the couple - looking at the individual only would lead to misleading conclusions for home production at the household level.

Similar models were also estimated for the separate home production activities in Section 3 (Tables 10 to 13). In particular, it is male hours of 'other' or 'semi-leisure chores' (mostly gardening and house repairs) and female hours of 'core' chores (mostly cleaning, ironing, washing dishes and clothes), cooking, and shopping that increase substantially upon (own) retirement. On weekdays, men in a couple devote almost three extra hours per day to 'other' chores upon their retirement, though this falls (by almost two hours) if their wife also retires. Remarkably, hours devoted to cooking and shopping at the household level and by the female partner increase significantly (by over one hour for cooking and almost 50 minutes for shopping) if the female partner retires. The time devoted to caring for others increases significantly for both partners with own retirement. ${ }^{6}$ At the household level, the largest effect is found if the male partner retires (almost one hour per day).

\section{Conclusion}

We have found that considering the effect of retirement on both partners in couple is crucial to understanding the effect of retirement on home production at the household level. There is a substantial increase in the hours of house work of males and females upon their own retirement that is larger for males than for females. Retirement of the female partner also significantly and substantially reduces the house work done by the man, but not vice versa.

\footnotetext{
${ }^{6}$ In the model with hours of paid work instead of the retirement status dummy, caring time by the male partner is particularly responsive - it increases by 15 minutes for a drop in paid work hours by one hour.
} 
This implies that ignoring the partner's retirement and its effect on home production may lead to a biased estimate of the scope for substitution between private expenditure and home production at the household level. Moreover, considering the effect of retirement of the male breadwinner only will also lead to an incomplete picture of how retirement affects time use and productive activities in the household.

Furthermore, the findings in our study at a less aggregate level suggest that the increase in house work hours of retired French men is mostly concentrated in activities such as gardening and house repairs, while for women in couple, mostly cooking and shopping increase at retirement. Thus, taking the retirement of women in a couple into account helps explaining the potential for substitution between consumption expenditures and home production upon retirement.

The asymmetry between responses of male and female partners is striking, both for home production (that is, house work at an aggregate level) and for more disaggregate time use categories such as shopping, cooking, and gardening.

\section{References}

Aguiar, Mark, and Eric Hurst. 2005. "Consumption versus Expenditure." Journal of Political Economy, 113(5): 919-948.

Aguiar, Mark, and Eric Hurst. 2007a. "Life-Cycle Prices and Production." American Economic Review, 97(5): 1533-1559.

Aguiar, Mark, and Eric Hurst. 2007b. "Measuring Trends in Leisure: The Allocation of Time over Five Decades," Quarterly Journal of Economics, 122(3): 969-1006. 
Battistin, Erich, Agar Brugiavini, Enrico Rettore and Guglielmo Weber. 2009. "The

Retirement Consumption Puzzle: Evidence from a Regression Discontinuity Approach."

American Economic Review, 99(5): 2209-2226.

Gustman, Alan L., and Thomas L. Steinmeier. 2000. "Retirement in Dual-Career Families: A Structural Model." Journal of Labor Economics, 18: 503-545.

Gustman, Alan L. and Thomas L. Steinmeier. 2009, "Integrating Retirement Models." NBER Working Paper 15607.

Hamermesh, Daniel S. 1984. "Consumption During Retirement: The Missing Link in the Life-Cycle." Review of Economics and Statistics, 66(1): 1-7.

Hurd, Michael A. 1990. "The Joint Retirement Decision of Husbands and Wives," in: Issues in the Economics of Aging, ed. David A. Wise, 231-258. Cambridge MA: National Bureau of Economic Research.

Hurd, Michael A., and Susann Rohwedder. 2008. "The Retirement Consumption Puzzle: Actual Spending Change in Panel Data." NBER Working Paper 13929.

Hurst, Eric. 2008. "The Retirement of a Consumption Puzzle." NBER Working Paper 13789.

Lee, David, S., and Thomas Lemieux. 2010. "Regression Discontinuity Designs in Economics." Journal of Economic Literature, 48(2): 281-355.

Roodman, David. 2007. "CMP: Stata module to implement conditional (recursive) mixed process estimator." Statistical Software Components S456882, Boston College Department of Economics, revised 22 May 2009.

Roodman, David. 2009. "Estimating Fully Observed Recursive Mixed-Process Models with CMP." Working Paper 168, Center for Global Development. 
Table 1. Descriptive Statistics Estimation Sample

\begin{tabular}{|c|c|c|c|c|}
\hline & \multicolumn{2}{|c|}{ Male partner } & \multicolumn{2}{|c|}{ Female partner } \\
\hline & Mean & standard deviation & Mean & $\begin{array}{l}\text { standard } \\
\text { deviation }\end{array}$ \\
\hline Age (in years) & 60.72 & 5.50 & 58.60 & 5.61 \\
\hline Age 60 or older & 0.57 & 0.49 & 0.43 & 0.47 \\
\hline Retired & 0.64 & 0.48 & 0.67 & 0.47 \\
\hline Housewife & 0 & 0 & 0.35 & 0.46 \\
\hline Employed & 0.36 & 0.48 & 0.32 & 0.47 \\
\hline Born in France & 0.96 & 0.18 & 0.97 & 0.16 \\
\hline $\begin{array}{l}\text { High School (12 } \\
\text { years schooling) }\end{array}$ & 0.12 & 0.32 & 0.10 & 0.30 \\
\hline $\begin{array}{l}\text { College and more } \\
\text { (over } 12 \text { years of } \\
\text { schooling) }\end{array}$ & 0.15 & 0.36 & 0.11 & 0.31 \\
\hline \multirow[t]{3}{*}{ Bad health } & 0.03 & 0.18 & 0.05 & 0.23 \\
\hline & & \multicolumn{2}{|c|}{ Household characteristics } & \\
\hline & & Mean & $\begin{array}{l}\text { standard } \\
\text { deviation }\end{array}$ & \\
\hline $\begin{array}{l}\text { Number of } \\
\text { children at home }\end{array}$ & & 0.15 & 0.51 & \\
\hline Cohabiting & & 0.04 & 0.19 & \\
\hline Resides in Paris & & 0.02 & 0.15 & \\
\hline $\begin{array}{l}\text { Regional } \\
\text { Unemployment } \\
\text { rate (percent) }\end{array}$ & & 11.45 & 2.46 & \\
\hline Weekend diary & & 0.23 & 0.42 & \\
\hline Observations & \multicolumn{4}{|c|}{1043} \\
\hline
\end{tabular}


Table 2. Participation Rates and Mean (median) Time Spent on Various Activities

\begin{tabular}{|c|c|c|c|c|c|c|}
\hline & \multicolumn{3}{|l|}{ Male partner } & \multicolumn{3}{|c|}{ Female partner } \\
\hline & $\begin{array}{l}\text { Participation } \\
\text { rate } \\
\text { (percent) }\end{array}$ & $\begin{array}{l}\text { Mean time } \\
\text { spent in } \\
\text { minutes per } \\
\text { day (st. } \\
\text { dev.) }\end{array}$ & $\begin{array}{l}\text { Median } \\
\text { time spent } \\
\text { (minutes } \\
\text { per day) }\end{array}$ & $\begin{array}{l}\text { Participation } \\
\text { rate } \\
\text { (percent) }\end{array}$ & $\begin{array}{l}\text { Mean time } \\
\text { spent in } \\
\text { minutes } \\
\text { per day } \\
\text { (st. dev.) }\end{array}$ & $\begin{array}{l}\text { Median } \\
\text { time spent } \\
\text { (minutes } \\
\text { per day) }\end{array}$ \\
\hline Market work & 29.82 & \begin{tabular}{|l|}
137.83 \\
$(235.46)$
\end{tabular} & 0 & 21.67 & $\begin{array}{c}86.04 \\
(182.88)\end{array}$ & 0 \\
\hline House work & 86.77 & \begin{tabular}{|l|}
183.70 \\
$(152.56)$
\end{tabular} & 160 & 99.04 & $\begin{array}{l}310.60 \\
(147.40)\end{array}$ & 310 \\
\hline $\begin{array}{l}\text { House work, } \\
\text { excluding } \\
\text { 'semi- } \\
\text { leisure' }\end{array}$ & 70.18 & $\begin{array}{r}77.19 \\
(88.64)\end{array}$ & 40 & 98.85 & $\begin{array}{l}264.85 \\
(123.81)\end{array}$ & 260 \\
\hline $\begin{array}{l}\text { 'Core' } \\
\text { Housework } \\
\text { (excludes a, } \\
\text { b, and c } \\
\text { below) }\end{array}$ & 50.81 & $\begin{array}{c}36.38 \\
(59.05)\end{array}$ & 10 & 96.07 & $\begin{array}{l}145.04 \\
(90.28)\end{array}$ & 140 \\
\hline Cooking, a & 29.63 & $\begin{array}{r}11.40 \\
(24.09)\end{array}$ & 0 & 93.38 & $\begin{array}{r}81.67 \\
(49.15)\end{array}$ & 80 \\
\hline Shopping, b & 40.84 & $\begin{array}{c}29.42 \\
(47.97)\end{array}$ & 0 & 52.06 & $\begin{array}{r}38.14 \\
(49.96)\end{array}$ & 10 \\
\hline $\begin{array}{l}\text { 'Semi- } \\
\text { leisure', } \\
\text { chores, c }\end{array}$ & 61.74 & \begin{tabular}{|l|}
106.51 \\
$(128.64)$
\end{tabular} & 60 & 43.72 & $\begin{array}{r}45.75 \\
(75.36)\end{array}$ & 0 \\
\hline $\begin{array}{l}\text { Caring for } \\
\text { children } \\
\text { and/or adults }\end{array}$ & 14.67 & $\begin{array}{r}17.66 \\
(66.12)\end{array}$ & 0 & 21.76 & $\begin{array}{c}24.31 \\
(65.13)\end{array}$ & 0 \\
\hline Observations & & & & & & \\
\hline
\end{tabular}


Chart 1. Retirement status and market work (in minutes per day): discontinuities at age 60

Chart 1. Retirement and Paid Work: discontinuities at age 60.
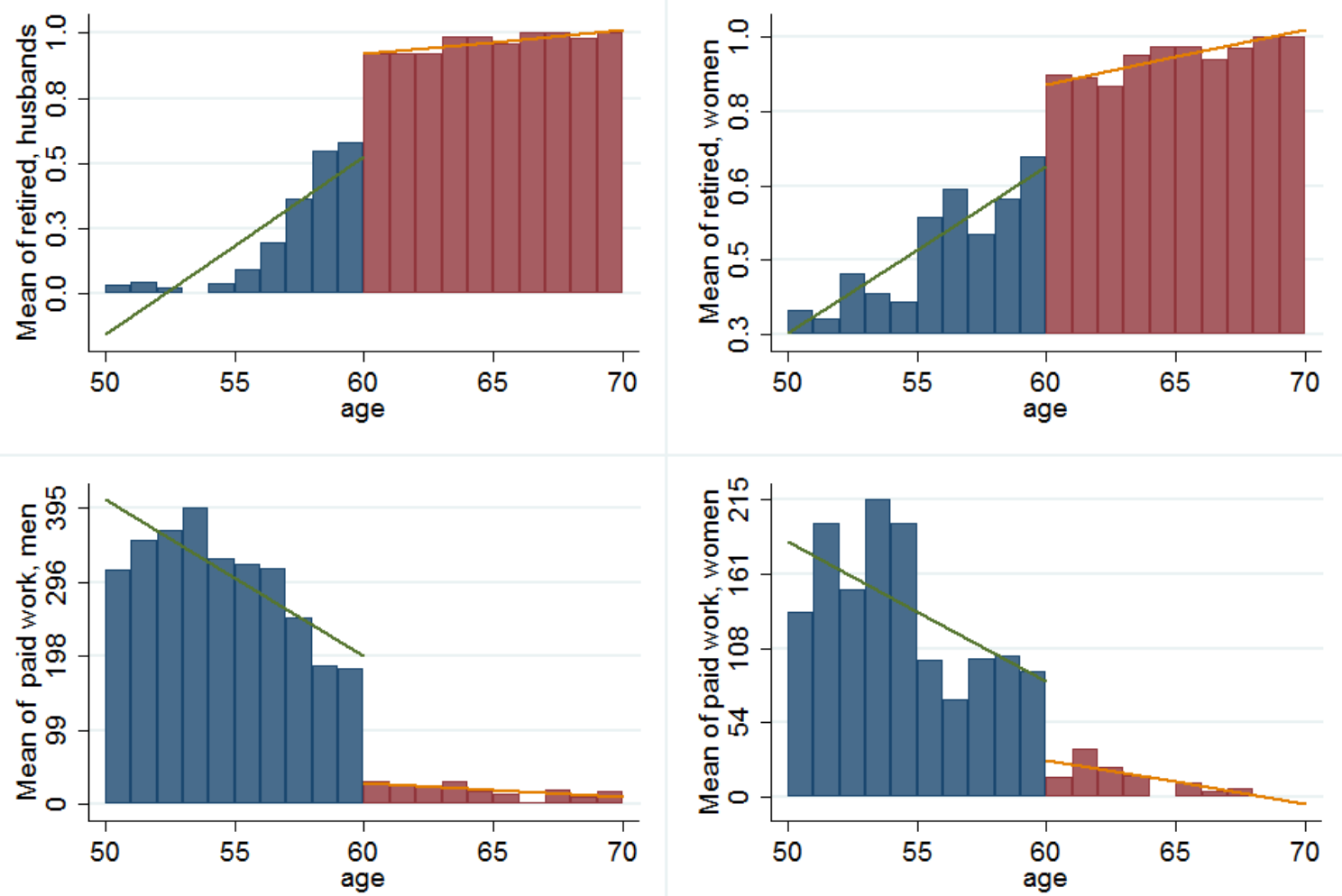
Chart 2. House work and care time (minutes per day): discontinuities at age 60
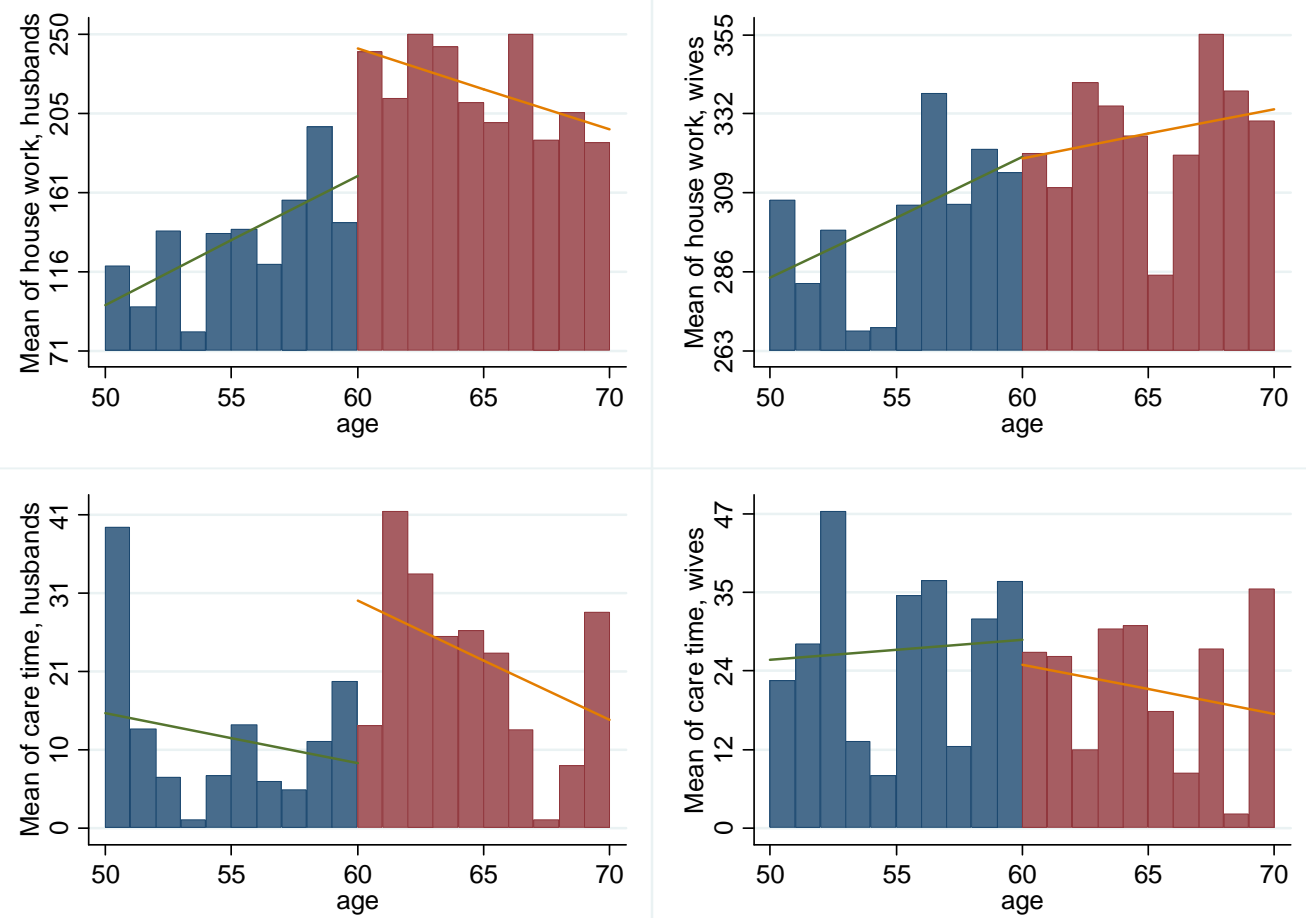
Table 3. Results of estimation of retirement and house work of partners: marginal effects

\begin{tabular}{|c|c|c|c|c|}
\hline & He retired & She retired & His Housework & Her Housework \\
\hline \multirow[t]{2}{*}{ Paris } & $-0.377 * * *$ & $-0.106 * *$ & $-79.57 * *$ & -13.42 \\
\hline & $(0.384)$ & $(0.326)$ & $(33.26)$ & $(30.96)$ \\
\hline \multirow[t]{2}{*}{ Unemployment rate } & -0.003 & 0.003 & -0.192 & -2.032 \\
\hline & $(0.0265)$ & $(0.0198)$ & $(1.817)$ & $(1.735)$ \\
\hline \multirow[t]{2}{*}{ He high school } & -0.059 & 0.031 & 0.930 & -8.850 \\
\hline & $(0.202)$ & $(0.155)$ & $(14.57)$ & (13.88) \\
\hline \multirow[t]{2}{*}{ He college and more } & $-0.115^{* *}$ & $-0.037 *$ & -5.911 & $-27.25^{*}$ \\
\hline & $(0.229)$ & $(0.163)$ & $(16.78)$ & $(15.70)$ \\
\hline \multirow[t]{2}{*}{ She high school } & $0.103 * *$ & -0.016 & 22.77 & $-38.92 * *$ \\
\hline & $(0.233)$ & $(0.165)$ & $(16.38)$ & $(15.53)$ \\
\hline \multirow{2}{*}{ She college and more } & -0.009 & $-0.095 * * *$ & -16.11 & $-36.94 *$ \\
\hline & $(0.267)$ & $(0.182)$ & $(19.85)$ & $(18.95)$ \\
\hline \multirow[t]{2}{*}{ Children number } & -0.009 & $0.018^{*}$ & 9.100 & $19.92 * *$ \\
\hline & $(0.130)$ & $(0.0841)$ & $(9.433)$ & $(9.008)$ \\
\hline \multirow[t]{2}{*}{ Cohabitant } & 0.014 & 0.036 & -23.04 & $-55.50 * *$ \\
\hline & $(0.290)$ & $(0.269)$ & $(23.23)$ & $(22.20)$ \\
\hline He age 60 or over & $\begin{array}{c}0.233 * * * \\
(0.396)\end{array}$ & $\begin{array}{c}-0.040 \\
(0.341)\end{array}$ & & \\
\hline She age 60 or over & $\begin{array}{c}-\mathbf{- 0 . 1 0 8} \\
(\mathbf{0 . 4 5 3})\end{array}$ & $\begin{array}{c}\mathbf{0 . 1 2 8} * * * \\
(0.369)\end{array}$ & & \\
\hline He retired & & & $\begin{array}{c}188.1 * * * \\
(61.17)\end{array}$ & $\begin{array}{c}47.38 \\
(45.63)\end{array}$ \\
\hline She retired & & & $\begin{array}{c}-107.0 * * \\
(49.10)\end{array}$ & $\begin{array}{c}159.4 * * * \\
(46.60)\end{array}$ \\
\hline Weekend Diary & & & $\begin{array}{c}59.81 * * * \\
(18.37)\end{array}$ & $\begin{array}{c}89.57 * * * \\
(18.00)\end{array}$ \\
\hline He retired*weekend diary & & & $\begin{array}{c}-129.0 * * * * \\
(23.49)\end{array}$ & $\begin{array}{l}-10.41 \\
(22.96)\end{array}$ \\
\hline She retired*weekend diary & & & $\begin{array}{c}7.309 \\
(\mathbf{2 3 . 9 3}) \\
\end{array}$ & $\begin{array}{c}-131.9 * * * \\
(23.41)\end{array}$ \\
\hline $\begin{array}{l}\text { Notes: The four equations are } \\
\text { draws. The explanatory varia } \\
\text { polynomials in age of the two } \\
\text { The time use equations incluc }\end{array}$ & $\begin{array}{l}\text { ted simultan } \\
\text { the retiremer } \\
\text { rs interacted } \\
\text { polynomial }\end{array}$ & $\begin{array}{l}\text { ously by simı } \\
\text { equations al } \\
\text { jith the dumr } \\
\text { in age of eac }\end{array}$ & $\begin{array}{l}\text { incd maximum lik } \\
\text { include left and } r \\
\text { for being } 60 \text { or o } \\
\text { partner. }\end{array}$ & $\begin{array}{l}\text { hood, with } 100 \\
\text { th cubic } \\
\text { er (see Section I). }\end{array}$ \\
\hline $\begin{array}{l}\text { Retirement equations are spe } \\
\text { the retirement equations are c } \\
\text { for dichotomous ones, assum } \\
\text { residence in Paris, formally } n\end{array}$ & $\begin{array}{l}\text { s probit, the } \\
\text { ed at the mea } \\
\text { than high sc } \\
\text { (not cohabiti }\end{array}$ & $\begin{array}{l}\text { buse work eq } \\
\text { value of the } \\
\text { ool (the refer } \\
\text { g) and that b }\end{array}$ & $\begin{array}{l}\text { tions are linear. } \\
\text { ontinuous explana } \\
\text { ce category) for } 1 \\
\text { are aged } 60 \text { year }\end{array}$ & $\begin{array}{l}\text { rginal effects for } \\
\text { y variables and, } \\
\text { h partners, no } \\
\text { or more. }\end{array}$ \\
\hline \multicolumn{5}{|c|}{ House work is measured in minutes per day and it includes all subcomponents (see Section II). } \\
\hline \multicolumn{5}{|c|}{ Standard errors in parentheses. $* * * \mathrm{p}<0.01, * * \mathrm{p}<0.05, * \mathrm{p}<0.1$} \\
\hline
\end{tabular}


Table 4. Results of estimation of market and house work of partners

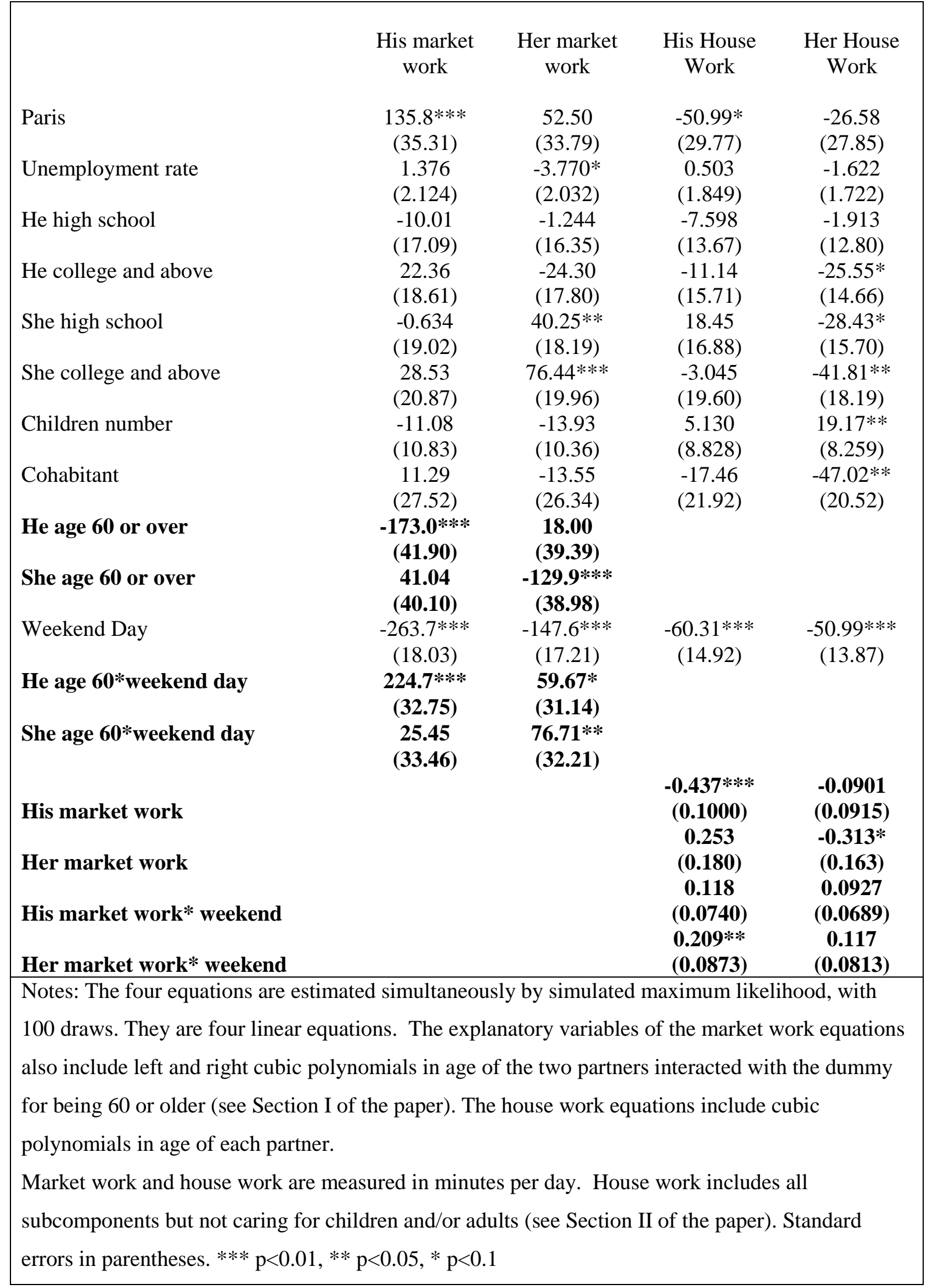


Table 5. Correlations of the errors in the model of Table 3

\begin{tabular}{|cccc|}
\hline & $\begin{array}{c}\text { She is } \\
\text { retired }\end{array}$ & $\begin{array}{c}\text { His } \\
\text { housework }\end{array}$ & $\begin{array}{c}\text { Her } \\
\text { housework }\end{array}$ \\
He is retired & $0.256^{* * *}$ & -0.025 & -0.318 \\
& $(0.0918)$ & $(0.025)$ & $(0.206)$ \\
She is & & & \\
retired & & $0.386^{*}$ & -0.093 \\
& & $(0.218)$ & $(0.218)$ \\
His & & & $0.239 * * *$ \\
housework & & & $(0.0442)$ \\
& & & \\
\hline
\end{tabular}

Table 6. Correlations of the errors in the model of Table 4

\begin{tabular}{|cccc|}
\hline & $\begin{array}{c}\text { Her } \\
\text { market } \\
\text { work }\end{array}$ & $\begin{array}{c}\text { His } \\
\text { house } \\
\text { work }\end{array}$ & $\begin{array}{c}\text { Her } \\
\text { house } \\
\text { work }\end{array}$ \\
$\begin{array}{c}\text { His } \\
\text { market } \\
\text { work }\end{array}$ & $0.342 * * *$ & -0.0573 & 0.262 \\
$\begin{array}{c}\text { Her } \\
\text { market } \\
\text { work }\end{array}$ & $(0.0310)$ & $(0.219)$ & $(0.212)$ \\
His house \\
work
\end{tabular}


Table 7. Coefficients on the left and right age polynomials interacted with dummy age $\geq 60$

\begin{tabular}{|c|c|c|c|c|}
\hline & \multicolumn{2}{|c|}{$\begin{array}{l}\text { Retirement model } \\
\text { (Table 3) }\end{array}$} & \multicolumn{2}{|c|}{$\begin{array}{l}\text { Market Work Model } \\
\text { (Table 4) }\end{array}$} \\
\hline & $\mathrm{He}$ is retired & She is retired & $\begin{array}{l}\text { His market } \\
\text { work }\end{array}$ & $\begin{array}{l}\text { Her market } \\
\text { work }\end{array}$ \\
\hline $\mathrm{Dm}=$ Husband is age 720 months (age 60) & $\begin{array}{c}1.060 * * * \\
(0.396)\end{array}$ & $\begin{array}{l}-0.311 \\
(0.341)\end{array}$ & $\begin{array}{c}-173.0^{* * *} \\
(41.90)\end{array}$ & $\begin{array}{l}18.00 \\
(39.39)\end{array}$ \\
\hline Dm * (Husband's age in months -720$)$ & $\begin{array}{c}0.357 \\
(0.332)\end{array}$ & $\begin{array}{c}0.179 \\
(0.229)\end{array}$ & $\begin{array}{l}-12.16 \\
(23.48)\end{array}$ & $\begin{array}{l}-9.244 \\
(22.27)\end{array}$ \\
\hline Dm * (Husband's age in months -720$)^{\wedge} 2$ & $\begin{array}{l}-0.0438 \\
(0.0940)\end{array}$ & $\begin{array}{l}-0.0259 \\
(0.0580)\end{array}$ & $\begin{array}{c}2.452 \\
(5.505)\end{array}$ & $\begin{array}{l}1.171 \\
(5.244)\end{array}$ \\
\hline Dm * (Husband's age in months -720$)^{\wedge} 3$ & $\begin{array}{c}0.00254 \\
(0.00715)\end{array}$ & $\begin{array}{c}0.00128 \\
(0.00410)\end{array}$ & $\begin{array}{l}-0.142 \\
(0.364)\end{array}$ & $\begin{array}{l}-0.0379 \\
(0.347)\end{array}$ \\
\hline$(1-\mathrm{Dm}) *($ Husband's age in months -720$)$ & $\begin{array}{l}-0.250 \\
(0.270)\end{array}$ & $\begin{array}{l}0.477 * * \\
(0.225)\end{array}$ & $\begin{array}{l}-16.06 \\
(28.60)\end{array}$ & $\begin{array}{c}-56.63 * * \\
(26.78)\end{array}$ \\
\hline$(1-\mathrm{Dm})^{*}(\text { Husband's age in months }-720)^{\wedge} 2$ & $\begin{array}{c}-0.193 * * * \\
(0.0710)\end{array}$ & $\begin{array}{l}0.0979 * \\
(0.0529)\end{array}$ & $\begin{array}{l}6.111 \\
(6.780)\end{array}$ & $\begin{array}{l}-10.85^{*} \\
(6.360)\end{array}$ \\
\hline$(1-\mathrm{Dm})^{*}(\text { Husband's age in months }-720)^{\wedge} 3$ & $\begin{array}{l}-0.0157 * * * \\
(0.00501)\end{array}$ & $\begin{array}{c}0.00551 \\
(0.00353)\end{array}$ & $\begin{array}{c}0.664 \\
(0.454)\end{array}$ & $\begin{array}{l}-0.485 \\
(0.427)\end{array}$ \\
\hline $\mathrm{Df}=\mathrm{Wife}$ is age 720 months (age 60) & $\begin{array}{l}-0.493 \\
(0.453)\end{array}$ & $\begin{array}{c}1.001 * * * \\
(0.369)\end{array}$ & $\begin{array}{c}41.04 \\
(40.10)\end{array}$ & $\begin{array}{c}-129.9 * * * \\
(38.98)\end{array}$ \\
\hline Df $*$ (Wife's age in months -720$)$ & $\begin{array}{l}0.572^{*} \\
(0.340)\end{array}$ & $\begin{array}{c}0.151 \\
(0.338)\end{array}$ & $\begin{array}{l}-38.77 \\
(23.58)\end{array}$ & $\begin{array}{l}-6.402 \\
(23.47)\end{array}$ \\
\hline Df $*(\text { Wife's age in months }-720)^{\wedge} 2$ & $\begin{array}{l}-0.0742 \\
(0.0940)\end{array}$ & $\begin{array}{r}-0.0509 \\
(0.106)\end{array}$ & $\begin{array}{c}6.651 \\
(5.753)\end{array}$ & $\begin{array}{c}1.016 \\
(5.645)\end{array}$ \\
\hline Df $*$ (Wife's age in months -720$)^{\wedge} 3$ & $\begin{array}{c}0.00202 \\
(0.00695)\end{array}$ & $\begin{array}{c}0.00642 \\
(0.00928)\end{array}$ & $\begin{array}{l}-0.316 \\
(0.396)\end{array}$ & $\begin{array}{l}-0.0722 \\
(0.384)\end{array}$ \\
\hline$(1-D f) *($ Wife's age in months -720$)$ & $\begin{array}{l}-0.0817 \\
(0.282)\end{array}$ & $\begin{array}{l}-0.256 \\
(0.175)\end{array}$ & $\begin{array}{l}-1.701 \\
(23.61)\end{array}$ & $\begin{array}{l}69.35 * * * \\
(22.13)\end{array}$ \\
\hline$(1-\mathrm{Df}) *(\text { Wife's age in months }-720)^{\wedge} 2$ & $\begin{array}{l}-0.0197 \\
(0.0607)\end{array}$ & $\begin{array}{l}-0.0682 * \\
(0.0389)\end{array}$ & $\begin{array}{c}1.371 \\
(5.182)\end{array}$ & $\begin{array}{l}18.28 * * * \\
(4.889)\end{array}$ \\
\hline$(1-\mathrm{Df}) *(\text { Wife's age in months }-720)^{\wedge} 3$ & $\begin{array}{l}-0.00132 \\
(0.00383)\end{array}$ & $\begin{array}{l}-0.00399 \\
(0.00247)\end{array}$ & $\begin{array}{l}0.0920 \\
(0.327) \\
\end{array}$ & $\begin{array}{c}1.137 * * * \\
(0.309)\end{array}$ \\
\hline \multicolumn{5}{|c|}{$\begin{array}{l}\text { Notes: Estimates of the coefficients of the other covariates are provided in Tables } 3 \text { and } 4 . \\
\text { Standard errors in parentheses } * * * p<0.01, * * \mathrm{p}<0.05, * \mathrm{p}<0.1\end{array}$} \\
\hline
\end{tabular}


Table 8. Models of retirement and house work: estimated effects of retirement

\begin{tabular}{|c|c|c|c|}
\hline & His house work ${ }^{1}$ & Her house work ${ }^{1}$ & His + Her house work ${ }^{2}$ \\
\hline $\mathrm{He}$ is retired & $\begin{array}{c}211.8 * * \\
(89.57)\end{array}$ & $\begin{array}{c}61.46 \\
(39.62)\end{array}$ & $\begin{array}{c}287.0 * * * \\
(78.43)\end{array}$ \\
\hline She is retired & $\begin{array}{c}-118.0 * * * \\
(45.56)\end{array}$ & $\begin{array}{c}115.6^{* * * *} \\
(42.93)\end{array}$ & $\begin{array}{c}71.13 \\
(117.7)\end{array}$ \\
\hline He is retired weekdays & $\begin{array}{c}188.1^{* * *} \\
(61.17)\end{array}$ & $\begin{array}{c}47.38 \\
(45.63)\end{array}$ & $\begin{array}{c}276.4 * * * \\
(94.22)\end{array}$ \\
\hline She retired weekdays & $\begin{array}{c}-107.0^{* *} \\
(49.10)\end{array}$ & $\begin{array}{c}159.4 * * * \\
(46.60)\end{array}$ & $\begin{array}{c}116.2 \\
(115.2)\end{array}$ \\
\hline He is retired weekends & $\begin{array}{c}59.09 \\
(64.97)\end{array}$ & $\begin{array}{c}36.97 \\
(49.52)\end{array}$ & $\begin{array}{c}139.7 \\
(101.1)\end{array}$ \\
\hline She retired weekends & $\begin{array}{l}-99.71 * \\
(52.66)\end{array}$ & $\begin{array}{c}27.47 \\
(40.50)\end{array}$ & $\begin{array}{l}-9.725 \\
(117.2)\end{array}$ \\
\hline \multicolumn{4}{|c|}{$\begin{array}{l}\text { (1) The four equations of partners' retirement and house work are estimated simultaneously by } \\
\text { simulated maximum likelihood. } \\
\text { (2) The three equations of each partner's retirement and total house work at the household level } \\
\text { (his plus her house work) are estimated simultaneously by simulated maximum likelihood. }\end{array}$} \\
\hline \multicolumn{4}{|c|}{$\begin{array}{l}\text { For both models, the explanatory variables of the retirement equations include dummies for } \\
\text { age } 60 \text { and older and left and right cubic polynomials in age of the two partners interacted with } \\
\text { the age } 60 \text { dummies (see Section I). The house work equations include cubic polynomials in age } \\
\text { of each partner. Other regressors included in all equations are: an indicator for whether the } \\
\text { couple resides in Paris; a cohabiting dummy; the regional unemployment rate; the number of } \\
\text { children; and indicators for whether each partner has high school or college and more education. }\end{array}$} \\
\hline
\end{tabular}


Table 9. Models of market hours and home production: estimated effects of market hours on house work time

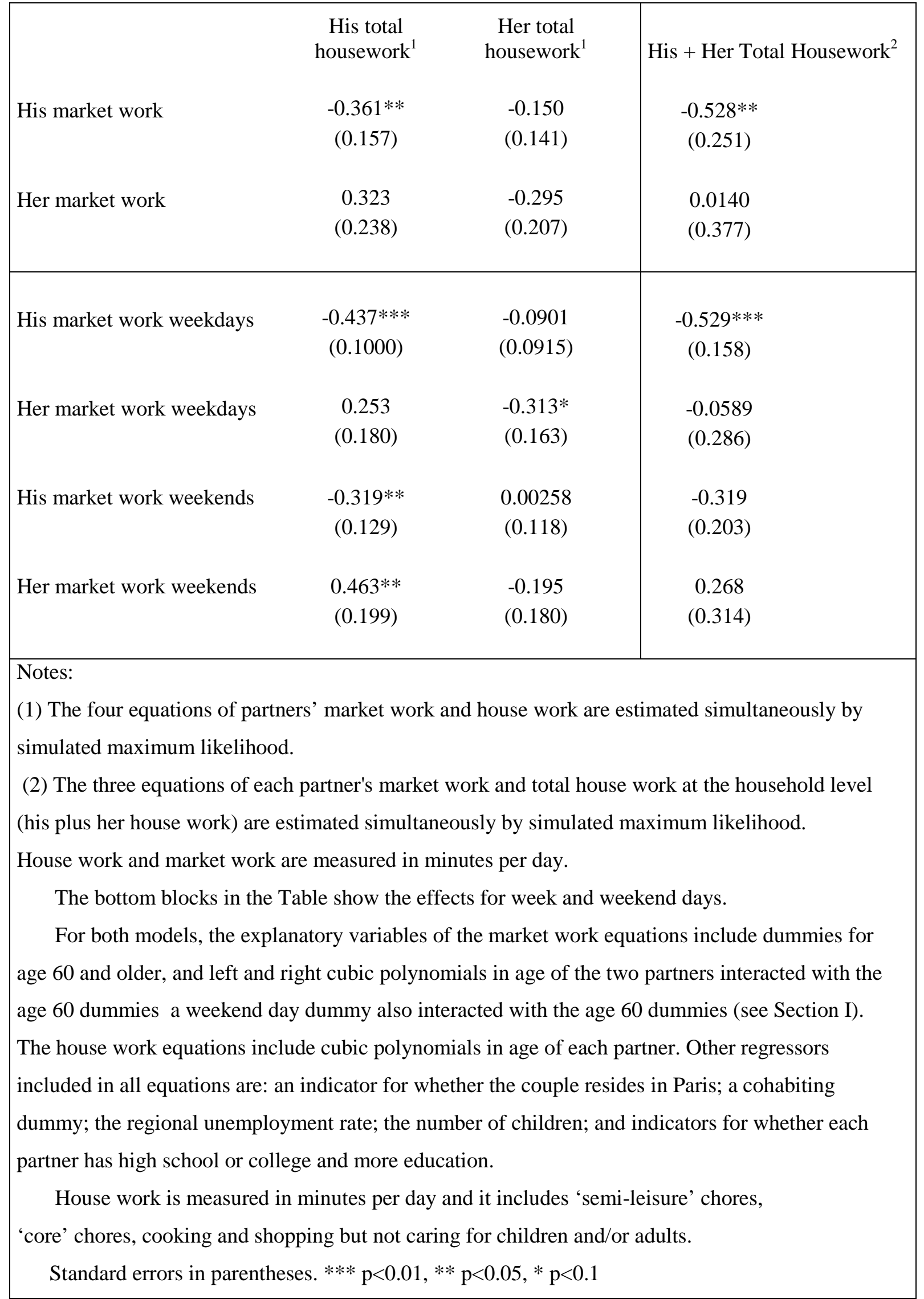

Table 10. Models of retirement and 'core' chores : estimated effects of retirement 


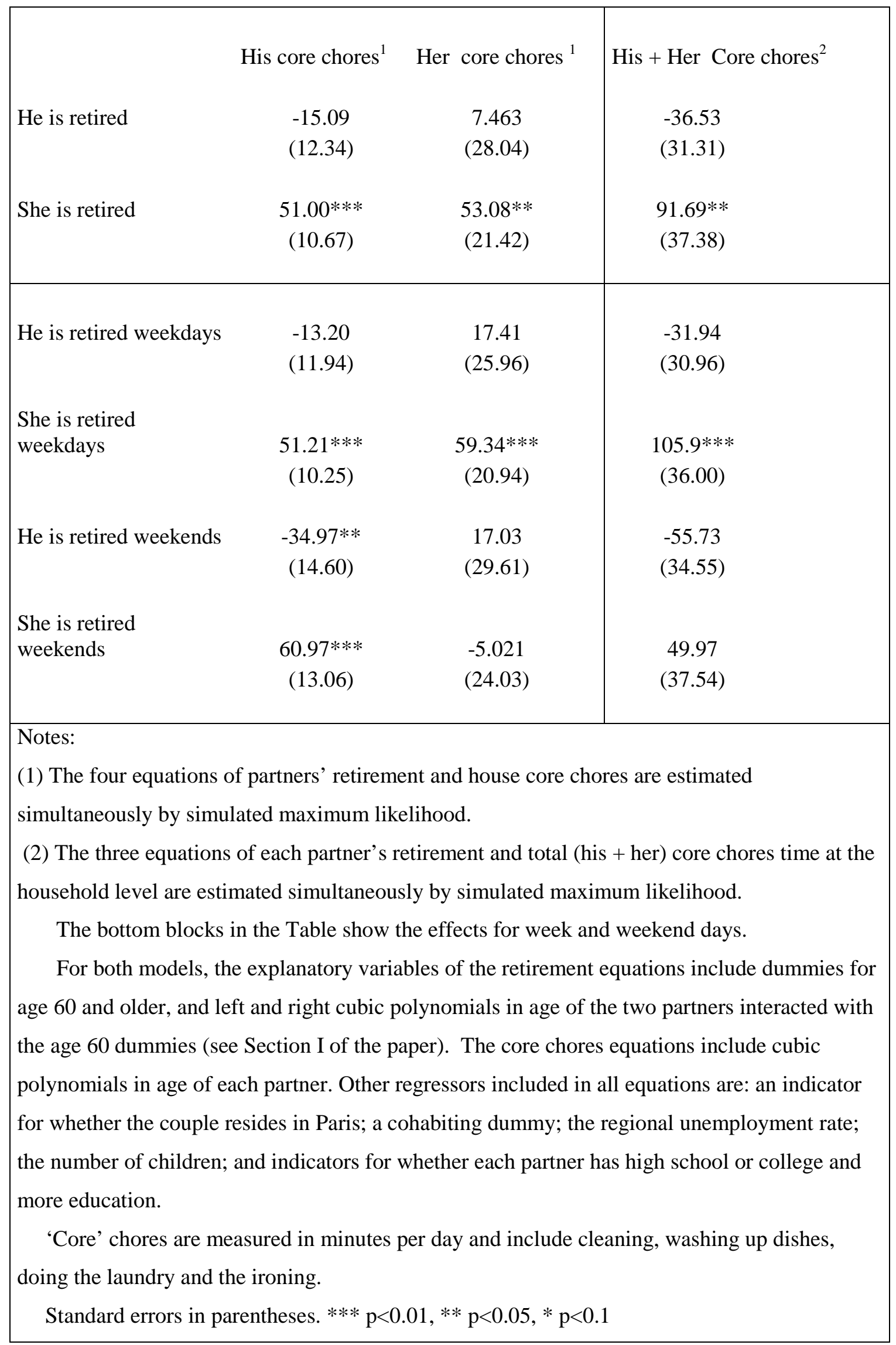

Table 11. Models of retirement and 'semi-leisure' chores : effects of retirement 


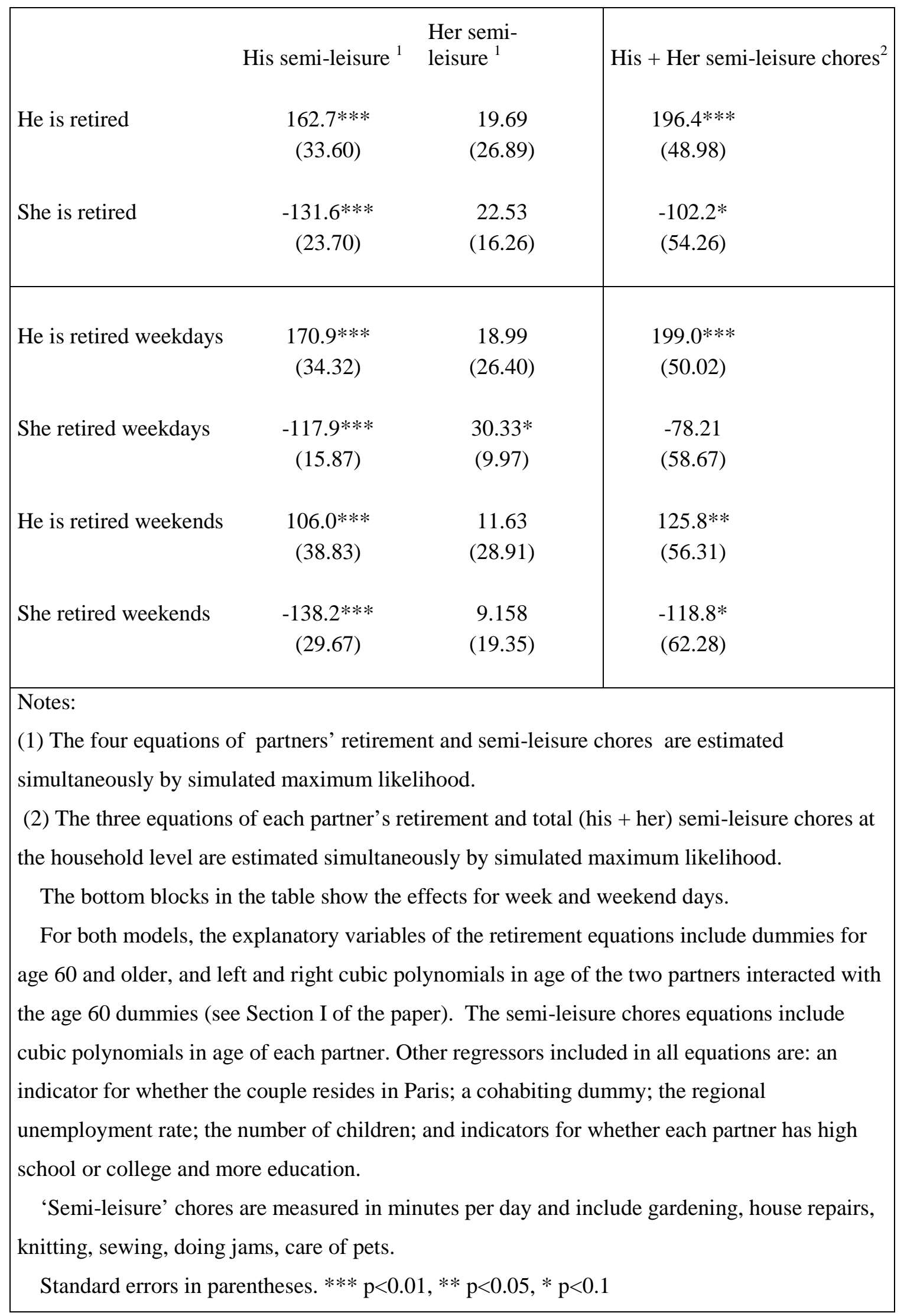


Table 12. Models of retirement and cooking: estimated effects of retirement

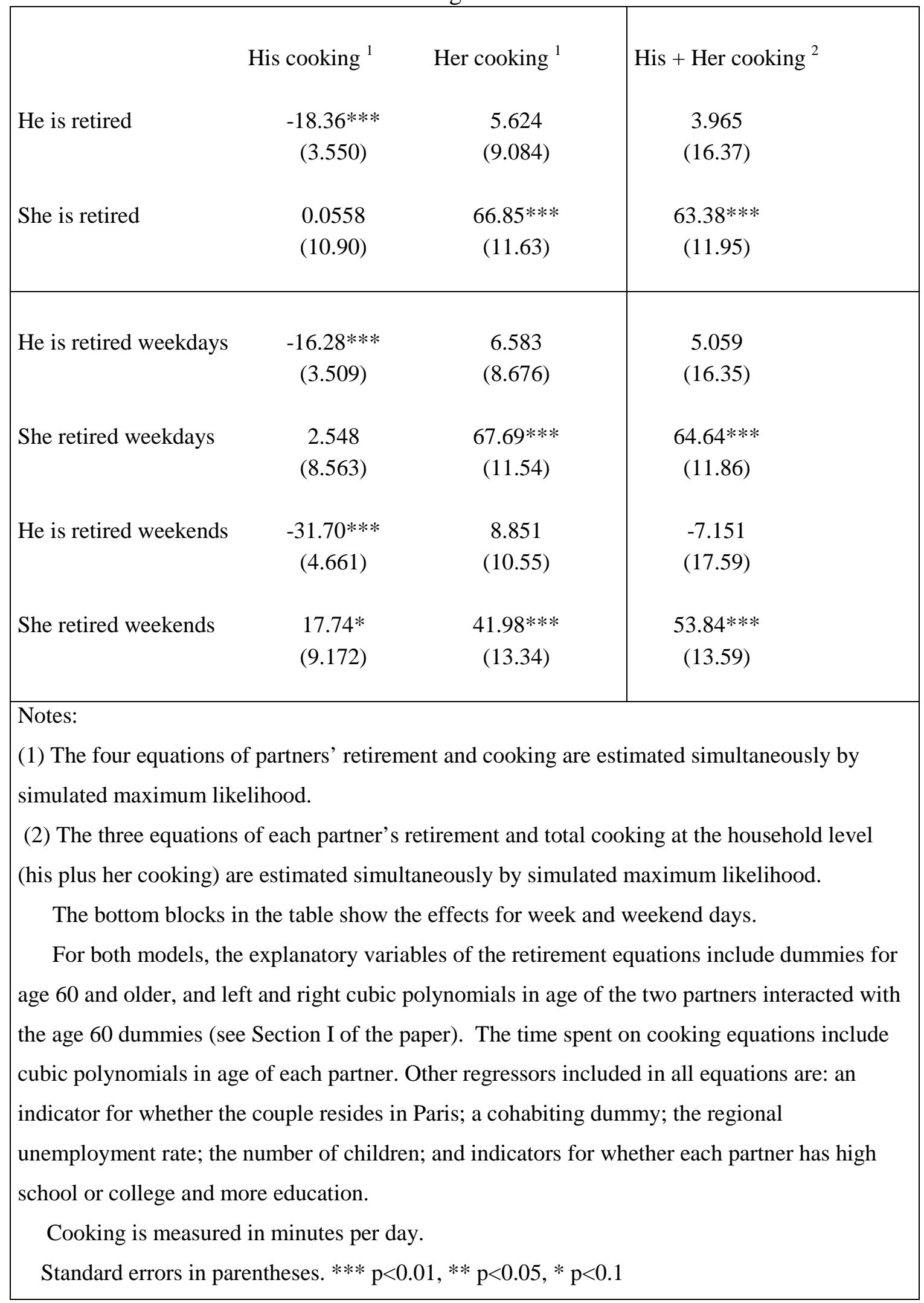


Table 13. Models of retirement and time spent on caring: estimated effects of retirement

\begin{tabular}{|c|c|c|c|}
\hline \multirow[b]{2}{*}{ He is retired } & His care ${ }^{1}$ & Her care $^{1}$ & \multirow{2}{*}{ His + Her Care ${ }^{2}$} \\
\hline & $\begin{array}{c}34.30 * * * \\
(11.47)\end{array}$ & $\begin{array}{c}13.97 \\
(15.89)\end{array}$ & \\
\hline She is retired & $\begin{array}{c}13.63 \\
(15.50)\end{array}$ & $\begin{array}{c}30.49 * * \\
(12.60)\end{array}$ & $\begin{array}{l}39.43 * \\
(23.94)\end{array}$ \\
\hline $\mathrm{He}$ is retired weekdays & $\begin{array}{c}37.79 * * * \\
(11.82)\end{array}$ & $\begin{array}{c}15.23 \\
(16.26)\end{array}$ & $\begin{array}{c}55.45 * * * \\
(20.53)\end{array}$ \\
\hline She retired weekdays & $\begin{array}{c}13.08 \\
(15.34)\end{array}$ & $\begin{array}{c}31.75^{* *} \\
(12.92)\end{array}$ & $\begin{array}{l}40.12 * \\
(24.25)\end{array}$ \\
\hline He is retired weekends & $\begin{array}{c}18.22 \\
(14.47)\end{array}$ & $\begin{array}{c}9.986 \\
(18.56)\end{array}$ & $\begin{array}{c}30.64 \\
(24.61)\end{array}$ \\
\hline She retired weekends & $\begin{array}{c}20.09 \\
(17.40)\end{array}$ & $\begin{array}{l}26.12 * \\
(15.32)\end{array}$ & $\begin{array}{c}41.44 \\
(27.47)\end{array}$ \\
\hline \multicolumn{4}{|c|}{$\begin{array}{l}\text { (2) The three equations of each partner's retirement and total care work at the household level } \\
\text { (his plus her care work) are estimated simultaneously by simulated maximum likelihood. } \\
\text { The bottom blocks in the Table show the effects for week and weekend days. }\end{array}$} \\
\hline $\begin{array}{l}\text { For both models, th } \\
\text { age } 60 \text { and older, and le } \\
\text { the age } 60 \text { dummies (se } \\
\text { each partner. Other regr } \\
\text { resides in Paris; a cohab } \\
\text { and indicators for whetl } \\
\text { Care is measured in } \\
\text { care, to individuals fron } \\
\text { Standard errors in pa }\end{array}$ & $\begin{array}{l}\text { explanatory va } \\
\text { t and right cub } \\
\text { Section I). Th } \\
\text { ssors included } \\
\text { ting dummy; tl } \\
\text { er each partner } \\
\text { ninutes per day } \\
\text { the same or fr } \\
\text { entheses. } * * * 1\end{array}$ & $\begin{array}{l}\text { les of the retire } \\
\text { lynomials in a } \\
\text { re equations in } \\
\text { ll equations are } \\
\text { gional unempl } \\
\text { high school or } \\
\text { it includes th } \\
\text { ther househol } \\
01, * * \mathrm{p}<0.05 \text {, }\end{array}$ & $\begin{array}{l}\text { equations include dummies for } \\
\text { he two partners interacted with } \\
\text { cubic polynomials in age of } \\
\text { dicator for whether the couple } \\
\text { t rate; the number of children; } \\
\text { sion of unpaid child and adult } \\
\text { siond education. }\end{array}$ \\
\hline
\end{tabular}

